\title{
EFEKTIVITAS MODEL PEMBELAJARAN COOPERATIVE LEARNING TIPE STAD UNTUK MENINGKATKAN HASIL BELAJAR SISWA PADA MATA PELAJARAN GEOGRAFI
}

\author{
MUHTAR \\ SMA Negeri 1 Wawo, Bima, NTB \\ E-mail: muhtarboke1974@gmail.com
}

\begin{abstract}
ABSTRAK
Hasil belajar geografi kelas IX SMA Negeri 1 Wawo rendah, ditunjukkan dengan rendahnya persentase pencapaian KKM. Salah satu penyebabnya adalah pemilihan model pembelajaran yang kurang tepat. Penelitian ini bertujuan untuk meningkatkan hasil belajar mata pelajaran geografi pada siswa kelas IX SMA Negeri 1 Wawo dengan menerapkan model pembelajaran kooperative learning tipe STAD. Penelitian ini menggunakan Penelitian Tindakan Kelas melalui tahapan : Perencanaan, Pelaksanaan, Observasi dan Evaluasi, Analisis dan Refleksi. Data dikumpulkan dengan menggunakan lembar observasi dan tes hasil belajar. Kemudian data dianalisa secara kuantitatif dan kualitatif. Hasil penelitian menunjukkan bahwa penerapan model pembelajaran cooperative learning tipe STAD dapat meningkatkan hasil belajar siswa pada mata pelajaran geografi kelas IX SMA Negeri 1 Wawo tahun pelajaran 2018/2019 yang ditunjukkan oleh pencapaian hasil belajar siswa dengan nilai rata-rata kelas 83,25. Berarti pada siklus II sudah mencapai ketuntasan klasikal 86\%.
\end{abstract}

Kata Kunci: Hasil belajar, cooperative learning, tipe STAD.

\section{PENDAHULUAN}

Pendidikan akan memberikan peluang yang besar pada siswa untuk memenuhi suatu harapan, serta pengetahuan supaya bisa hidup secara lebih baik. Besarnya peluang serta harapan sangat tergantung pada mutu pembelajaran yang ditempuh. Dengan pendidikan akan menjadi bekal kekuatan guna melaksanakan perubahan agar suatu keadaan akan menjadi lebih baik. Dalam pendidikan yang bermutu dan bermartabat pastinya akan mempengaruhi siswa menjadi aktif belajar serta mengarahkan terbentuknya nilai-nilai yang diperlukan oleh siswa dalam menempuh kehidupan.(Riama, 2018)

Menurut UU SISDIKNAS No. 20 Tahun 2003 Bab 1 pasal 1 butir 1 menjelaskan bahwa :

"Pendidikan adalah usaha sadar dan terencana untuk mewujudkan suasana belajar dan proses pembelajaran agar peserta didik secara aktif mengembangkan potensi dirinya untuk memiliki kekuatan spiritual keagamaan, pengendalian diri, kepribadian, kecerdasan, akhlak mulia, serta keterampilan yang diperlukan dirinya, masyarakat, bangsa dan negara. Untuk mengembangkan potensi yang ada didalam diri manusia maka tidak lepas dari dunia pendidikan".

Untuk melaksanakan pendidikan sangat perlu adanya suatu lembaga pendidikan formal. Menurut Hamalik (dalam Sudana \& Wesnawa 2017: 1) menjelaskan bahwa sekolah sebagai suatu lembaga pendidikan formal, secara sistematis merencanakan bermacam-macam lingkungan, yakni lingkungan pendidikan yang menyediakan berbagai kesempatan bagi peserta didik untuk melakukan berbagai kegiatan belajar. Dengan berbagai kesempatan belajar, pertumbuhan dan perkembangan peserta didik diarahkan dan didorong ke arah pencapaian tujuan yang dicita-citakan. Lingkungan tersebut disusun dan ditata dalam suatu kurikulum, yang pada gilirannya dilaksanakan dalam bentuk proses pembelajaran.

Wesley (dalam Syamsuddin, 2016: 106) menjelaskan bahwa pembelajaran Geografi adalah suatu program pendidikan yang memilih bahan pendidikan dari disiplin ilmu-ilmu sosial dan humaniti, yang diorganisir dan disajikan secara ilmiah dan psikologis untuk tujuan pendidikan. 
Pembelajaran geografi memiliki peranan yang penting pada jenjang pendidikan menengah atas, sehingga sangat penting untuk diajarkan, hal ini disebabkan siswa yang belajar di sekolah berasal dari wilayah dan masyarakat yang berbeda- beda. Melalui pembelajaran geografi, siswa diharapkan mampu membaca dan menyelesaikan permasalahan yang muncul di lingkungannya. Tidak hanya itu, dengan pengajaran geografi siswa bisa mendapatkan pengetahuan, keahlian, perilaku, serta kepekaan guna kelangsungan hidup dan kehidupan dengan berbagai tantangan yang ada. Dalam rangka mewujudkan keberhasilan dalam pendidikan Geografi sebaiknya seseorang guru mampu menerapkan berbagai inovasi pembelajaran dalam penyampaian materi pengajaran salah satunya pada mata pelajaran Geografi. Inovasi dalam pembelajaran dapat dilakukan dengan memilih dan menerapkan berbagai metode dan model pembelajaran yang sesuai sehinga dapat menarik, memotivasi, serta melibatkan siswa belajar, dan juga dengan menyediakan media pembelajaran yang sesuai.(Feriana, 2016)

Mata pelajaran geografi dalam konsep umum kerapkali dipandang sebagai mata pelajaran hafalan yang membosankan perihal tersebut bisa kita amati dari terdapatnya ketidaktuntasan siswa pada saat ulangan setiap menyelesaikan kompetensi dasar, sehingga para guru geografi wajib mulai meningkatkan sistim pendidikan inovatif buat membangkitkan atensi siswa terhadap pelajaran geografi.

Fakta menunjukkan bahwa pembelajaran geografi di SMA kurang optimal. Kekurangoptimalan dalam pelaksanaan pembelajaran geografi ini adalah kurangnya motivasi dan penguasaan siswa terhadap materi geografi. Demikian yang terjadi pada siswa kelas XI SMA Negeri 1 Wawo Kabupaten Bima, khususnya pada pembelajaran tentang sebaran dan pengelolaan sumber daya alam di Indonesia. Hasil belajar yang diperoleh siswa masih sangat rendah. Dari 32 siswa hanya 60\% yang mencapai nilai KKM 72 yang di tentukan oleh sekolah pada awal pelajaran baru. Data tersebut dapat dilihat pada tabel di bawah ini.

Tabel 1. Data awal hasil tes formatif Geografi kelas XI SMA Negeri 1 Wawo Tahun Pelajaran 2017/2018

\begin{tabular}{cccc}
\hline No. & NILAI & JUMLAH SISWA & KETERANGAN \\
\hline 1 & 85 & 1 & TUNTAS \\
2 & 80 & 3 & TUNTAS \\
3 & 75 & 15 & TUNTAS \\
4 & 60 & 5 & TIDAK TUNTAS \\
5 & 55 & 5 & TIDAK TUNTAS \\
6 & 50 & 3 & TIDAK TUNTAS \\
& TOTAL & 32 & \\
\hline
\end{tabular}

Data di atas berdasarkan hasil test formatif Geografi Kelas XII Tahun Pelajaran 2017/2018. Hal di atas dapat disebabkan oleh berbagai hal berikut:

(1)Kurang bervariasinya metode pembelajaran yang digunakan, yaitu masih menggunakan metode pembelajaran konvensional berupa metode ceramah. (2) Kegiatan pembelajaran di dalam kelas masih didominasi oleh guru, (3) Kurangnya pemberdayaan kemampuan siswa dalam proses pembelajaran. (4) Guru kurang menggunakan media mengajar.

Kondisi demikian berdampak pada rendahnya aktivitas belajar siswa di dalam kelas, sehingga mempengaruhi hasil belajar siswa. Untuk mengatasi permasalah di atas telah dikembangkan suatu pendekatan dan model pembelajaran kooperatif untuk menghasilkan tujuan belajar yang lebih baik. Salah satunya adalah model pembelajaran kooperatif tipe STAD.

"Student Team Achievement Divisions (STAD) adalah salah satu tipe pembelajaran kooperatif yang paling sederhana. Siswa ditempatkan dalam tim belajar beranggotakan empat orang yang merupakan campuran menurut tingkat kinerjanya, jenis kelamin dan suku. Guru menyajikan pelajaran kemudian siswa 
bekerja dalam tim untuk memastikan bahwa seluruh anggota tim telah menguasai pelajaran tersebut. Akhirnya seluruh siswa dikenai kuis tentang materi itu dengan catatan, saat kuis mereka tidak boleh saling membantu. Model Pembelajaran Koperatif tipe STAD merupakan pendekatan Cooperative Learning yang menekankan pada aktivitas dan interaksi diantara siswa untuk saling memotivasi dan saling membantu dalam menguasai materi pelajaran guna mencapai prestasi yang maksimal. Guru yang menggunakan STAD mengajukan informasi akademik baru kepada siswa setiap minggu mengunakan presentasi Verbal atau teks."(Mukrimah, 2014:108-109)

Selanjutnya Suherman, dkk (dalam Paiman, 2013:205) menjelaskan bahwa dengan pembelajaran kooperatif siswa akan termotivasi untuk belajar dengan baik, siap dengan pekerjaannya, penuh perhatian selama kegiatan pembelajaran berlangsung, serta dapat meningkatkan kemampuan siswa dalam memecahkan masalah dan berpikir kritis.

Selain dari pendekatan dan model pembelajaran yang di gunakan, untuk meningkatkan hasil belajar siswa juga tidak terlepas dari faktor internal dan eksternal. Wasliman (dalam Feriana, 2016: 5), menjelaskan bahwa hasil belajar siswa dipengaruhi oleh dua faktor, yaitu faktor internal dan eksternal. Faktor internal adalah faktor dari dalam diri siswa, sedangkan faktor eksternal adalah berasal dari luar diri siswa. Faktor eksternal meliputi sekolah, keluarga, dan masyarakat. Salah satu faktor yang mempengaruhi hasil belajar adalah faktor eksternal yaitu sekolah. Sekolah sangat penting untuk mencapai keberhasilan belajar. Salah satu hal yang mempengaruhi motivasi dan hasil belajar siswa di sekolah adalah model atau model belajar yang digunakan oleh guru. Hakekat belajar adalah suatu aktivitas yang mengharapkan perubahan tingkah laku pada diri individu yang belajar. Perubahan tingkah laku terjadi karena usaha individu yang bersangkutan.

Pernyataan tersebut juga diperkuat oleh Majid (dalam Nurhasanah \& Sobandi, 2016: 130) menjelaskan bahwa hasil belajar siswa dipengaruhi oleh dua faktor yaitu faktor internal dan faktor eksternal siswa. Faktor internal siswa diantaranya meliputi gangguan kesehatan, cacat tubuh, faktor psikologis (intelegensi, minat belajar, perhatian, bakat, motivasi, kematangan dan kesiapan peserta didik), dan faktor kelelahan. Sedangkan faktor eksternal yang mempengaruhi proses dan hasil belajar siswa meliputi faktor keluarga, sekolah dan masyaraka.

Model pembelajaran koperatif tipe STAD pada kompetensi dasar sebaran dan pengelolaan sumber daya alam di Indonesia sangat sesuai di terapkan karena materi pelajaran Geografi dan khususnya materi pengelolaan sumber daya alam di Indonesia adalah pelajaran yang mengungkap fakta- fakta, serta informasi seputar ruang yang menjadi tempat tinggal manusia. Metode yang digunakan dalam pembelajaran materi pengelolaan sumber daya alam di Indonesia berkisar metode ceramah, diskusi, dan pemberian materi dan tugas dengan penugasan pekerjaan rumah. Guru tidak menerapkan sebuah teknik ataupun media yang bisa digunakan agar anak lebih tertarik dan tertantang. Atas dasar itu, maka peneliti merasa perlu melakukan penelitian terhadap permasalahan yang dihadapi di kelas XI SMA Negeri 1 Wawo Bima. Penelitian ini diharapkan bisa membawa dampak positif bagi guru dan siswa dalam rangka peningkatan kualitas proses dan hasil pembelajaran.

Tujuan penelitian ini adalah untuk mengetahui peningkatan hasil belajar siswa pada kompetensi dasar sebaran dan pengelolaan sumber daya alam di Indonesia melalui penerapan metode pembelajaran kooperatif tipe STAD (Student Teams Achievement Divisions).

\section{METODE PENELITIAN}

Pada penelitian ini menggunakan penelitian tindakan kelas (PTK). Penelitian ini dilaksanakan di kelas XI Sekolah Menengah Atas Negeri 1 Wawo Bima. Subjek penelitian ini adalah siswa kelas XI Sekolah Menengah Atas Negeri 1 Wawo Bima dengan jumlah siswa 36 orang. Data dalam penelitian ini dikumpulkan dari berbagai sumber yang meliputi: (1) dokumen atau arsip sekolah mengenai data siswa, kurikulum, dan silabus, (2) hasil belajar geografi setelah siswa melakukan kegiatan pembelajaran dengan model 
pembelajaran Kooperatif (cooperative learning) tipe STAD, dan (3) peristiwa proses pembelajaran dengan model pembelajaran Kooperatif (cooperative learning).

Pengumpulan data penelitian dilakukan dengan obersvasi kelas, observasi aktivitas guru, observasi aktivitas siswa, angket siswa, tes hasil belajar, dan catatan lapangan, kemudian data dianalisa secara kuantitatif dan kualitatif. Penelitian tindakan kelas melalui 4 tahap yaitu : perencanaan, pelaksanaan tindakan, observasi, dan refleksi, yang dilaksanakan dalam dua siklus (tiap siklus dilakukan 3 kali tatap muka). Observasi dilakukan bersamaan dengan dilaksanakannya suatu tindakan. Tujuan observasi adalah untuk mengumpulkan data yang didapat dari kinerja guru dan aktivitas siswa selama proses pembelajaran berlangsung. Langkah yang diambil, pertama peneliti melakukan observasi bagaimana model STAD diterapkan. Kemudian langkah selanjutnya peneliti merekam data atau membuat catatan lapangan menganai hal-hal yang terjadi selama pembelajaran.

Hasil yang didapat dalam tahap observasi dikumpulkan serta dianalisis. Pada tahap ini , guru dapat merefleksi diri berdasarkan hasil observasi dan diskusi. Untuk mengkaji apakah tindakan yang telah dilakukan dapat meningkatkan proses dan hasil belajar siswa pada mata pelajaran geografi. Hasil analis data yang dilakukan dalam tahapan akan dipergunakan sebagai acuan untuk merencanakan siklus berikutnya

\section{HASIL DAN PEMBAHASAN}

\section{Hasil}

Hasil analisis terhadap hasil belajar siswa siklus I terlihat pada tabel dibawah ini:

Tabel 2. Data hasil belajar siswa siklus I

\begin{tabular}{cccc}
\hline No. & NILAI & $\begin{array}{c}\text { JUMLAH } \\
\text { SISWA }\end{array}$ & KETERANGAN \\
\hline 1 & 85 & 3 & Tuntas \\
2 & 80 & 8 & Tuntas \\
3 & 75 & 14 & Tuntas \\
4 & 70 & 3 & Tidak tuntas \\
5 & 60 & 5 & Tidak tuntas \\
6 & 55 & 3 & Tidak tuntas \\
Nilai rata-rata hasil belajar & \multicolumn{2}{c}{ Orang } \\
Siswa tidak tuntas & \multicolumn{2}{c}{$\begin{array}{c}\text { 11 Orang } \\
\text { Siswa tuntas }\end{array}$} \\
Peresentase ketuntasan & \multicolumn{2}{c}{$69,44 \%$} \\
\hline
\end{tabular}

Hasil belajar siswa berdasarkan 4analisis hasil evaluasi pada siklus I ini belum maksimal artinya masih banyak siswa yang belum tuntas dilihat dari pencapaian nilai. Demikian juga dengan rata-rata kelas belum mencapai kriteria yang ditentukan. Secara umum minat untuk memahami materi masih rendah terlihat dari hasil tes formatif, dari $72 \mathrm{KKM}$ yang ditetapkan hanya mencapai $69.44 \%$.

Pada siklus II terlihat adanya peningkatan minat siswa secara mandiri ataupun kelompok, tampak lebih tinggi dan dikategorikan baik. Keseriusan kelompok baik sekali karena guru dan peneliti terlihat lebih fokus dalam memperhatikan aktivitas siswa, interaksinya dengan teman sudah baik, terlihat dari awal sudah menunjukkan kesungguhan/ keseriusan untuk berdiskusi. Siswa yang akademiknya tinggi, berusaha berbagi ide dengan anggota masing-masing, mereka lebih berekspresi dan bekerjasama yang lebih baik.

Pada siklus II ini dari empat kelompok yang ada, dapat menyelesaikan tugas dengan baik dan hasilnya memuaskan serta dengan waktu yang tepat, sehingga hasil tes formatif dari KKM yang ditetapkan 72 pada siklus II ini mencapai $86 \%$ berarti KKM sudah tercapai. 
Hasil analisis terhadap hasil belajar siswa siklus II terlihat pada tabel dibawah ini:

Tabel. 3 Data hasil belajar siswa siklus II

\begin{tabular}{cccc}
\hline No. & NILAI & $\begin{array}{c}\text { JUMLAH } \\
\text { SISWA }\end{array}$ & KETERANGAN \\
\hline 1 & 95 & 4 & Tuntas \\
2 & 90 & 4 & Tuntas \\
3 & 85 & 12 & Tuntas \\
4 & 80 & 5 & Tuntas \\
5 & 75 & 6 & Tuntas \\
6 & 70 & 3 & Tidak tuntas \\
7 & 65 & 2 & Tidak Tuntas \\
Jumlah siswa & \multicolumn{3}{c}{ 36 Orang } \\
Nilai rata-rata hasil belajar & \multicolumn{3}{c}{5 Orang } \\
Siswa tidak tuntas & \multicolumn{3}{c}{ 31 Orang } \\
Siswa tuntas & \multicolumn{2}{c}{$86 \%$} \\
Persentase ketuntasan &
\end{tabular}

Meningkatnya aktifitas guru dalam pembelajaran dilihat dari observasi aktifitas guru dari $65 \%$ pada siklus I menjadi $85 \%$ pada siklus II. Begitu juga dengan aktifitas siswa dalam pembelajaran dilihat dari observasi siswa dari $63 \%$ pada siklus I menjadi $84 \%$ pada siklus II.

\section{Pembahasan}

Setelah diamati dan didiskusikan serta dilakukan refleksi selama pelaksaanan penelitian tindakan di lapangan, maka dapat dipaparkan temuanya sebagai berikut :

Kemampuan awal siswa masih relatif rendah dan ini dapat diupayakan dengan melakukan pembelajaran kooperative learning tipe STAD. Dalam penerapan model pembelajaran ini siswa pada mulanya terlihat masih bingung dan canggung untuk berinteraksi dengan temannya sehingga pada siklus I, hasilnya belum memuaskan. Adapun hasil pada siklus I adalah: 1) Aktivitas siswa menunjukkan aktifitas siswa $63 \%$ (tergolong cukup baik). 2) Kegiatan belajar guru menunjukkan $65 \%$ (tergolong cukup baik), dan 3) Hasil belajar siswa baru mencapai 69,44 \% ketuntasan belajar klasikal dengan nilai rata-rata 73,00 dan ini belum mencapai target yang diharapkan. Pada siklus II terlihat kecanggungan untuk berinteraksi dan berbagi ide dapat diatasi dan suasana belajar mulai terlihat lebih baik.

Di samping itu, guru lebih aktif untuk mengontrol aktifitas kelompok, sehingga siswa lebih serius dalam memikirkan dan menyelesaikan tugas yang diberikan. Kondisi kelas dan kerja kelompok menunjukkan perubahan yang lebih baik. Mereka lebih santai, rileks, dan riang dalam menyelesaikan tugas-tugas yang diberikan. Data proses dan hasil belajar siswa pada siklus II adalah sebagai berikut : 1) Aktifitas siswa menunjukkan $84 \%$ (kategori sangat aktif). 2) Kegiatan mengajar guru $85 \%$ (kategori sangat baik) dan 3) Hasil belajar siswa mencapai $86 \%$ ketuntasan belajar klasikal dengan nilai rata-rata kelas 83,25. Data perbandingan hasil belajar siswa pada siklus I dan siklus II, menunjukkan adanya peningkatan yang cukup berarti, sehingga mencapai target yang telah diharapkan. Perbandingan hasil belajar siswa pada sikus 1 dengan siklus II ditunjukkan pada Tabel 3. 
Tabel. 3 Perbandingan hasil belajar siswa pada siklus I dengan siklus II

\begin{tabular}{|c|l|c|c|}
\hline No. & \multicolumn{1}{|c|}{ Uraian } & $\begin{array}{c}\text { Hasil Siklus } \\
\text { I }\end{array}$ & Hasil Siklus II \\
\hline 1. & Nilai Tertinggi & 85 & 95 \\
2. & Nilai Terendah & 55 & 65 \\
3. & Nilai rata-rata hasil belajar & 73,00 & 83,25 \\
4. & Jumlah siswa yang tuntas belajar & 25,00 & 31,00 \\
5. & Jumlah siswa yang tidak tuntas & 11.00 & 05.00 \\
6. & Persentase ketuntasan belajar & $69,44 \%$ & $86 \%$ \\
\hline
\end{tabular}

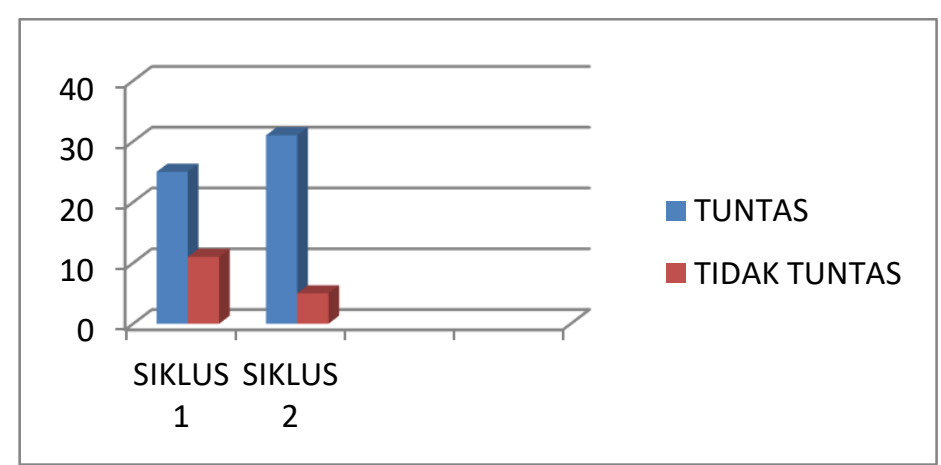

Gambar. 1 Perbandingan Ketuntasan hasil belajar siswa pada siklus I dengan siklus II

Berdasarkan hasil yang didapat dalam Penelitian Tindakan Kelas ini serta didukung oleh teori dan peneliti-peneliti lain sebelumnya antara lain; penelitian Paiman (2013), penelitian Syamsuddin (2016) dan penelitian Sudana \& Wesnawa (2017). Dalam penelitiannya, Paiman menyatakan bahwa pembelajaran menggunakan strategi pembelajaran kooperatif tipe STAD (Student Teams Achievement Divisions) dapat meningkatkan keaktifan belajar dan hasil belajar Geografi. Demikian juga dalam penelitian Syamsuddin (2016) menyatakan bahwa model pembelajaran kooperatif tipe STAD dapat meningkatkan hasil belajar geografi. Penelitian lain yang sangat mendukung adalah penelitian yang dilakukan oleh Sudana \& Wesnawa (2017).

Dalam penelitianya menyatakan bahwa melalui pembelajaran kooperatif STAD ada peningkatan dalam beberapa hal yaitu (1) keaktifan siswa meningkat dalam kegiatan kelompok, mengerjakan tugas- tugas dan berpikir bersama, (2) hasil belajar siswa meningkat pada ranah kognitif, afektif, dan psikomotor, (3) respon terhadap proses pembelajaran juga meningkat. Berdasarkan hasil dari beberapa peneliti tersebut Penulis punya keyakinan yang kuat, bahwa dengan penerapan model pembelajaran kooperatif tipe STAD dapat meningkatkan keaktifan dan hasil belajar siswa pada mata pelajaran geografi.

Hasil observasi di kelas, menunjukkan bahwa siswa yang berkemampuan tinggi terlihat lebih aktif dan antusias, sehingga memunculkan kerjasama serta mau berinteraksi, saling membantu serta berbagi pendapat, dan mau mendengarkan pendapat teman dalam menyelesaikan tugas. Dari empat kelompok siswa semuanya dapat menyelesaikan tugas dengan baik sesuai dengan waktu yang telah ditentukan. Melalui pembelajaran kooperatif tipe STAD, siswa membangun sendiri pengetahuan, menemukan langkah-langkah dalam mencari penyelesaian dari suatu materi yang harus dipahami dan dikuasai oleh siswa, baik secara individu maupun kelompok. Penerapan pembelajaran kooperatif tipe STAD dapat meningkatkan hasil belajar siswa.

\section{KESIMPULAN}

Berdasarkan data, analisis data dan pembahasan tentang upaya yang dilakukan untuk meningkatkan hasil belajar siswa melalui pembelajaran kooperative learning tipe STAD dapat disimpulkan bahwa penerapan model pembelajaran kooperative learning tipe STAD 
ternyata dapat meningkatkan hasil belajar siswa pada mata pelajaran geografi kelas IX SMA Negeri 1 Wawo tahun pelajaran 2018/2019 yang ditunjukkan oleh pencapaian hasil belajar siswa dengan nilai rata-rata kelas 83,25 berarti pada siklus II sudah mencapai ketuntasan klasikal 86\%.

\section{DAFTAR PUSTAKA}

Feriana, T. (2016). Efektivitas Penerapan Model Pembelajaran Discovery Based Learning Dan Group Investigation Pada Mata Pelajaran Geografi ... 68. https://lib.unnes.ac.id/27316/

Mukrimah, S. S. (2014). 53 Metode Belajar Pembelajaran (pp. 1-212).

Nurhasanah, S., \& Sobandi, A. (2016). Minat Belajar Sebagai Determinan Hasil Belajar Siswa. Jurnal Pendidikan Manajemen Perkantoran, $1(1), \quad 128$. https://doi.org/10.17509/jpm.v1i1.3264

Paiman. (2013). Upaya Meningkatkan Aktivitas Belajar Dan Hasil Belajar Siswa Pada Pembelajaran Geografi Dengan Menggunakan Metode Kooperatif (Cooperative Learning) Tipe Stad Di Kelas Xi Sma Negeri 2 Pontianak. Jurnal Edukasi, 11(2), 203216.

Riama, P. D. (2018). Model Pembelajaran Discovery Learning Untuk Meningkatkan Aktivitas dan Hasil Belajar Geografi Siswa SMA Negeri 1 Kasui Kabupaten Way Kanan.

Sudana, I. P. A., \& Wesnawa, I. G. A. (2017). Penerapan Model Pembelajaran Kooperatif Tipe STAD Untuk Meningkatkan Hasil Belajar IPA. Jurnal Ilmiah Sekolah Dasar, 1, 8. https://doi.org/10.33578/jpfkip.v7i1.5359

Syamsuddin. (2016). Upaya meningkatkan hasil belajar geografi melalui penerapan model pembelajaran kooperatif tipe stad. Volume V,(1), 104-115.

Undang-undang Republik Indonesia Nomor 20 Tahun 2003 tentang Sistem Pendidikan Nasional. 2006. Jakarta: diperbanyak oleh Departemen Pendidikan Nasional. 